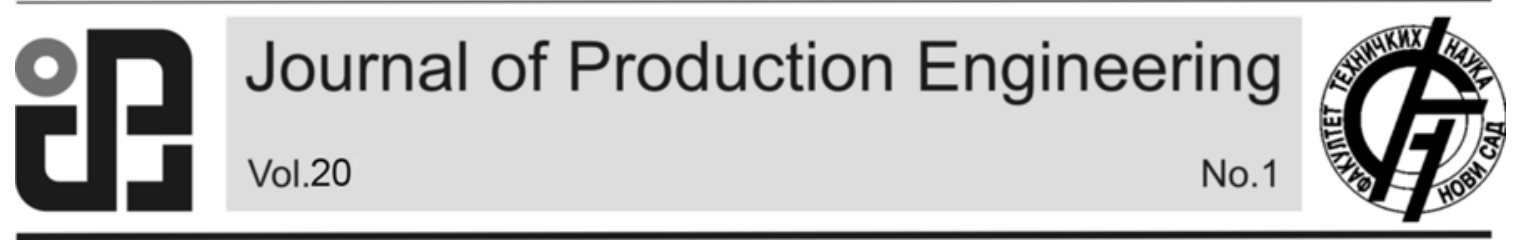

JPE (2017) Vol.20 (1)

Mohapatra, C. R.

Preliminary Note

\title{
A STUDY ON NATURAL CONVECTION HEAT TRANSFER IN COMPLEX BOUNDARIES
}

Received: 23 February 2017 / Accepted: 01 April 2017

\begin{abstract}
In the present work a computer code has been developed for heat transfer problems. SIMPLE algorithm based on finite volume method has been used. Deferred QUICK scheme have been implemented for all calculations. To solve momentum, pressure correction and energy equations, a solver (Line-by-Line solver) is used. This code is used for natural convection problems for $\mathrm{Ra}=10^{3}, 10^{4}, 10^{5}, 10^{6}$ and $\mathrm{Pr}=0.71$. The results were compared with the benchmark solution of de Vahl Davis, Markatos and Perikleous and Hadjisophocleous et al. for Ra $=10^{3} ; 10^{4} ; 10^{5}$, $10^{6}$ and $\mathrm{Pr}=0.71$. Very good agreements were obtained except for the $x$ and $y$ location of the maximum $u$ and $v$ velocity to the mid-plane.
\end{abstract}

Key words: rayleigh number, finite volume method, benchmark solutions, complex boundaries

Studija o prirodnoj konvekciji toplote u složenim granicama. U ovom radu kompjuterski kod je razvijen za probleme prenosa toplote. Korišćen je jednostavan algoritam na osnovu metoda konačnih zapremina. Odložena brza šema je primenjena za sve kalkulacije. Da bi se rešio impuls, korekcija pritiska i jednačine energije, primenjeno je rešenje (red-po-red). Ovaj kod se koristi za probleme sa prirodnim konvekcionim za Ra =103, 104, 105, 106 i PR = 0.71. Rezultati su poređeni sa referentnim rastvorom de Vahl Davis [4], Markatos i Perikleous [7] $i$ Hadjisophocleous et al. [8] za Ra =103; 104; 105, 106 i Pr =0,71. Dobijeno je vrlo dobri slaganje, osim za $x$ i y lokacije maksimalne u $i$ v brzine do sredine ravni.

Ključne reči: Raileigh broj, metoda konačnih zapremina, referentna rješenja, složene granice

\section{INTRODUCTION}

Natural convection flows are driven by the density difference that can arise in a fluid, with these density differences causing a buoyancy force which drives the flow. The density difference can be caused by temperature gradients in the fluid. Natural convection has many practical applications. It is important in the fields of cooling of micro-electric devices, nuclear reactors, electronic equipment, solar collectors, ventilations of rooms, atmospheric study etc. Patankar and Spalding [1] proposed SIMPLE(Semi-Implicit Method for Pressure-Linked Equation) algorithm method that became very popular for solving fluid flow problems. Ghia et al. [2] solved lid driven cavity flow using finite difference vortices-stream function method. Day to day natural convection heat transfer in complex boundaries are getting importance in engineering fields and many researchers have been focused to make a study in this area [3, 4]. Van Doormal and Raithby [5] proposed a popular version like SIMPLE that helped to increase the convergent rate. Their version is better known as the SIMPLEC algorithm where $\mathrm{C}$ refers to the word consistent. Maliska and Raithby [6] developed a method known as finite volume method for solving fluid flow problems using non-orthogonal grids and SIMPLEC algorithm. A good number of research has been carried out on natural convection in enclosures as it is a topic of considerable engineering importance. [4, 5, 7]. Hadjisophocleous et al. [7] used non-orthogonal boundary fitted coordinate system to solve the natural convection of a square cavity problem and compared the results with that of de Vahl Davis [4] and Markatos and Perikleous [8]. Thompson et al.[9] used the coordinate transformation technique to solve the problems over complex geometry.

\section{GOVERNING EQUATIONS}

Governing equations for two dimensional laminar, no viscous, incompressible, steady flows with Boussinesq approximation in dimensionless form can be written as follows Continuity equation:

$$
\frac{\partial U}{\partial X}+\frac{\partial V}{\partial Y}=0
$$

$\mathrm{X}$-Momentum equation:

$\frac{\partial(U)^{2}}{\partial X}+\frac{\partial(U V)}{\partial Y}=-\frac{\partial P}{\partial X}+\operatorname{Pr}\left(\frac{\partial^{2} U}{\partial X^{2}}+\frac{\partial^{2} U}{\partial Y^{2}}\right)+R a \operatorname{Pr} T \cos \phi^{(2)}$ $\mathrm{Y}$ - Momentum equation:

$$
\frac{\partial(U V)}{\partial X}+\frac{\partial\left(V^{2}\right)}{\partial Y}=-\frac{\partial P}{\partial Y}+\operatorname{Pr}\left(\frac{\partial^{2} V}{\partial X^{2}}+\frac{\partial^{2} V}{\partial Y^{2}}\right)+R a \operatorname{Pr} T \sin \phi^{(3)}
$$

Energy equation:

$\frac{\partial(U T)}{\partial X}+\frac{\partial(V T)}{\partial Y}=\frac{\partial^{2} T}{\partial X^{2}}+\frac{\partial^{2} T}{\partial Y^{2}}$

Where,

$$
\begin{aligned}
& X=\frac{x}{H}, Y=\frac{y}{H}, U=\frac{u H}{\alpha}, V=\frac{v H}{\alpha}, P=\frac{p H^{2}}{\rho \alpha^{2}}, \\
& T=\frac{T^{\prime}-T_{c}}{T_{h}-T_{c}}, \operatorname{Pr}=\frac{v}{\alpha}, R a=\frac{g \beta H^{3}\left(T_{h}-T_{c}\right)}{\alpha v}
\end{aligned}
$$


$x$ and $y$ are the distances, $u$ and $v$ are the velocity components measured along the horizontal and vertical directions, $H$ is the side of the cavity, $p$ is the pressure and $\rho$ is the density, $T_{\mathrm{h}}$ and $T_{\mathrm{c}}$ are the temperatures at hot and cold walls, $\beta$ is the volume of coefficient of expansion, $\alpha$ is the thermal diffusivity and $v$ is the kinematic viscosity.

\section{BOUNDARY CONDITIONS}

The figure 1 shows the boundary conditions of the natural convection in a two dimensional square cavity whose top and bottom walls are adiabatic and side walls are isothermal.

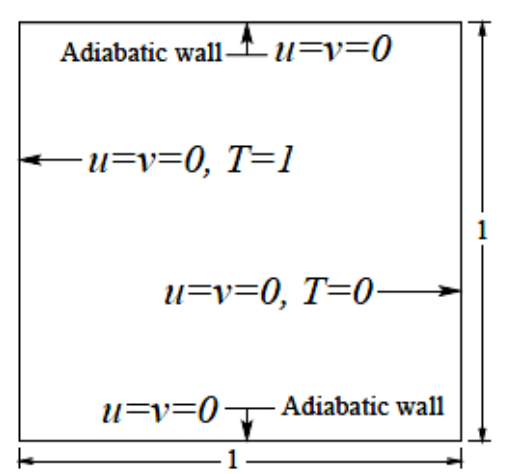

Fig. 1. Geometry and boundary conditions of the problem

\section{NUSSELT NUMBER CALCULATION}

In the present work, the Nusselt number is used to calculate the rate of heat transfer by convection. This can be possible by knowing the heat transfer rate by convection in an enclosure and temperature distribution in the fluid. Mathematically, it can be written as:

[a] $\mathrm{Ra}=10^{3}$

Observation

\begin{tabular}{|c|c|c|c|c|c|}
\hline Observation & $\mathbf{m}$ & $\mathbf{n}$ & $\mathbf{0}$ & $\mathbf{p}$ & $100 \times(p-m) / p$ \\
\hline$u_{\max }$ & 3.65 & 3.54 & 3.54 & 3.66 & 0.30 \\
\hline$y$ & 0.81 & 0.83 & 0.81 & 0.72 & - \\
\hline$v_{\max }$ & 3.70 & 3.59 & 3.59 & 3.70 & 0.24 \\
\hline$x$ & 0.18 & 0.19 & 0.19 & 0.26 & - \\
\hline $\mathrm{Nu}$ & 1.12 & 1.11 & 1.14 & 1.10 & -1.18 \\
\hline$N u_{\max }$ & 1.50 & 1.50 & 1.54 & 1.49 & -0.94 \\
\hline $\mathrm{y}$ & 0.09 & 0.08 & 0.14 & 0.13 & - \\
\hline$N u_{\min }$ & 0.69 & 0.72 & 0.73 & 0.67 & -3.28 \\
\hline$y$ & 1.000 & 0.992 & 0.991 & 0.991 & - \\
\hline
\end{tabular}

[b] $\mathrm{Ra}=10^{4}$

\begin{tabular}{|c|c|c|c|c|c|}
\hline Observation & $\mathbf{m}$ & $\mathbf{n}$ & $\mathbf{0}$ & $\mathbf{p}$ & $100 \times(p-m) / p$ \\
\hline $\mathrm{u}_{\max }$ & 16.18 & 16.18 & 16.00 & 16.29 & 0.700 \\
\hline $\mathrm{y}$ & 0.82 & 0.83 & 0.81 & 0.74 & - \\
\hline $\mathrm{V}_{\max }$ & 19.62 & 19.44 & 18.89 & 19.74 & 0.64 \\
\hline $\mathrm{x}$ & 0.12 & 0.11 & 0.10 & 0.19 & - \\
\hline $\mathrm{Nu}$ & 2.24 & 2.20 & 2.29 & 2.22 & -0.90 \\
\hline $\mathrm{Nu}_{\max }$ & 3.53 & 3.48 & 3.84 & 3.51 & -0.66 \\
\hline $\mathrm{y}$ & 0.14 & 0.14 & 0.14 & 0.16 & - \\
\hline $\mathrm{Nu}_{\min }$ & 0.59 & 0.64 & 0.67 & 0.57 & -2.99 \\
\hline $\mathrm{y}$ & 1.000 & 0.992 & 0.991 & 0.991 & - \\
\hline
\end{tabular}


[c] $\mathrm{Ra}=10^{5}$

\begin{tabular}{|c|c|c|c|c|c|}
\hline Observation & $\mathbf{m}$ & $\mathbf{n}$ & $\mathbf{0}$ & $\mathbf{p}$ & $100 \times(p-m) / p$ \\
\hline $\mathrm{u}_{\max }$ & 34.73 & 35.73 & 37.14 & 34.99 & 0.63 \\
\hline $\mathrm{y}$ & 0.86 & 0.86 & 0.86 & 0.78 & - \\
\hline$V_{\max }$ & 68.59 & 69.08 & 68.91 & 68.79 & 0.29 \\
\hline $\mathrm{x}$ & 0.067 & 0.067 & 0.061 & 0.125 & - \\
\hline $\mathrm{Nu}$ & 4.52 & 4.43 & 4.96 & 4.48 & -0.78 \\
\hline $\mathrm{Nu}_{\max }$ & 7.12 & 7.63 & 8.93 & 7.58 & 6.13 \\
\hline $\mathrm{y}$ & 0.081 & 0.082 & 0.080 & 0.091 & - \\
\hline $\mathrm{Nu}_{\min }$ & 0.73 & 0.82 & 1.01 & 0.70 & -3.99 \\
\hline$y$ & 1.00 & 0.99 & 1.00 & 0.99 & - \\
\hline
\end{tabular}

[d] $\mathrm{Ra}=10^{6}$

\begin{tabular}{|c|c|c|c|c|c|}
\hline Observation & $\mathbf{m}$ & n & $\mathbf{0}$ & $\mathbf{p}$ & $100 \times(p-m) / p$ \\
\hline $\mathrm{u}_{\max }$ & 64.63 & 68.81 & 66.42 & 64.99 & 0.554 \\
\hline $\mathrm{y}$ & 0.85 & 0.87 & 0.90 & 0.77 & - \\
\hline $\mathrm{V}_{\max }$ & 217.40 & 221.80 & 226.40 & 221.27 & 1.749 \\
\hline $\mathrm{x}$ & 0.038 & 0.037 & 0.021 & 0.075 & - \\
\hline $\mathrm{Nu}$ & 8.80 & 8.75 & 10.39 & 8.91 & 1.27 \\
\hline $\mathrm{Nu}_{\max }$ & 17.92 & 17.87 & 21.41 & 20.04 & 10.58 \\
\hline $\mathrm{y}$ & 0.038 & 0.037 & 0.030 & 0.025 & - \\
\hline $\mathrm{Nu}_{\min }$ & 0.99 & 1.23 & 1.58 & 0.92 & -7.97 \\
\hline $\mathrm{y}$ & 1.00 & 0.99 & 1.00 & 0.99 & - \\
\hline
\end{tabular}

m-solution of de Vahl Davis [4]; n- solution of Markatos and Perikleous [8]; o- solution of Hadjisophocleous et al [7]; p- present solution on $61 \times 61$ grid.

Table 1. Comparison of solutions for natural convection in an enclosed cavity

Fig. 2 shows the $u$ velocity profile along the vertical centerline of the cavity and $v$ velocity profile along the horizontal centerline. Very good agreements were obtained except for the $\mathrm{x}$ and $\mathrm{y}$ location of the maximum $\mathrm{u}$ and $\mathrm{v}$ velocity to the mid-plane. With increase of $\mathrm{Ra}$, the intensity of convection increased. Small values of the Rayleigh number corresponded to low convective heat transport i.e., the case of pure conduction. Fig. 3(a) shows the streamlines of a single vortex with circular shape and in Fig. 3(b) isotherms are parallel to the heated walls, indicating that most of the heat transfer is by heat conduction $\left(\mathrm{Ra}=10^{3}\right)$. Fig .4(a) shows the central streamline is distorted into an elliptic

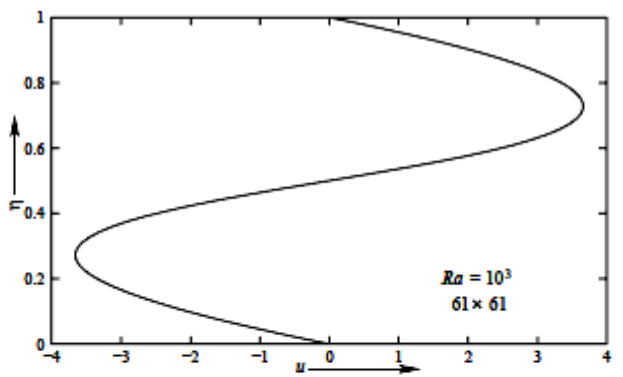

(a)

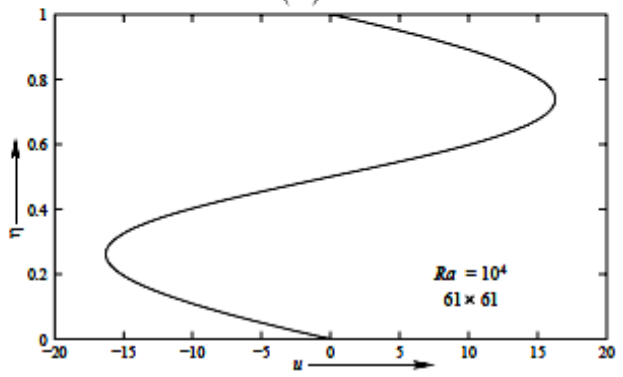

(c) shape and in Fig. 4(b), the effect of convection is more pronounced in the isotherms $\left(\mathrm{Ra}=10^{4}\right)$. As the Rayleigh number increases, the central streamline is further elongated and two secondary vortices appear inside it shown in Fig. 5(a). At $\mathrm{Ra}=10^{6}$, it is found that the secondary vortices move closer towards the walls and a third vortex appears in the centre of the section, again rotating clockwise as shown in Fig. 6(a). As the fluid moves near the walls, the heat transfer is mostly by convection. The flow of all cases is rotationally symmetric about the center of the cavity.

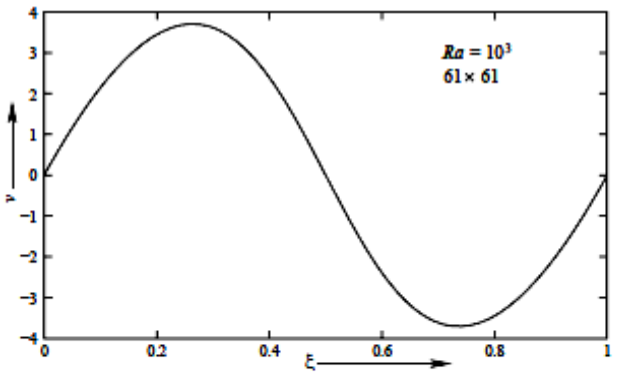

(b)

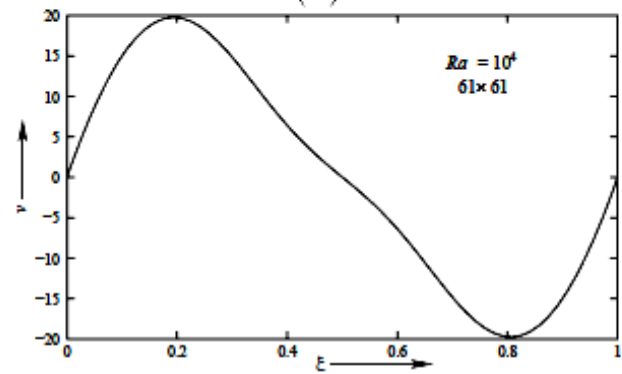

(d) 


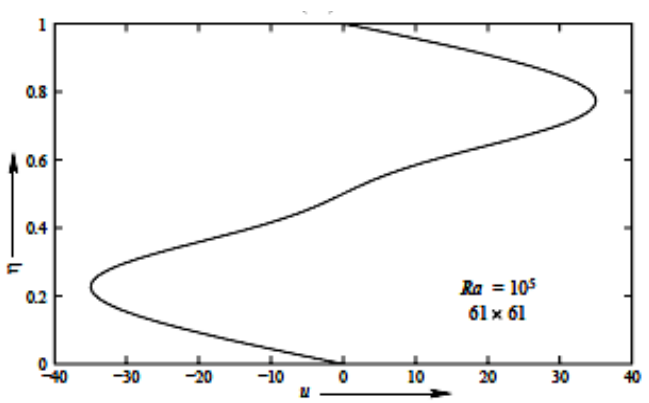

(e)

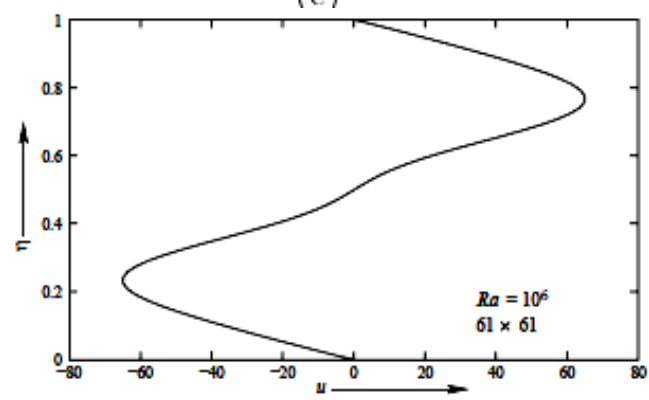

$(\mathrm{g})$

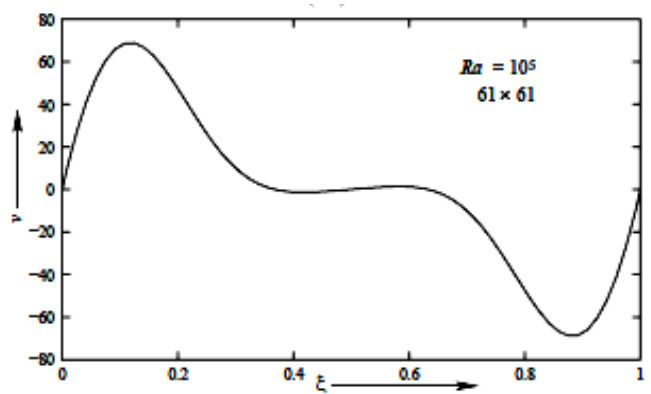

(f)

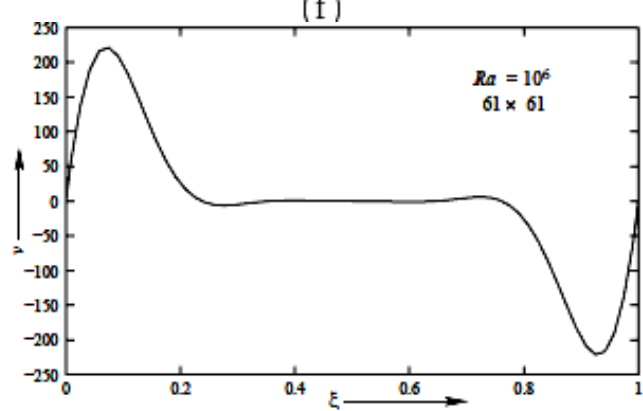

(h)

$v$ - Velocity along horizontal centerline

$u$-Velocity along vertical centerline

Fig. 2. $u$ and $v$ velocity plot for $\mathrm{Ra}=10^{3}, \mathrm{Ra}=10^{4}, \mathrm{Ra}=10^{5}$ and $\mathrm{Ra}=10^{6}$

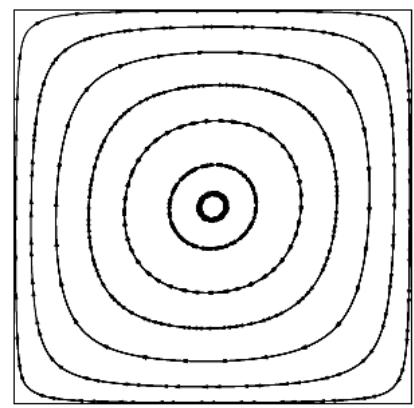

(a)

Fig. 3. $\mathrm{Ra}=10^{3}$

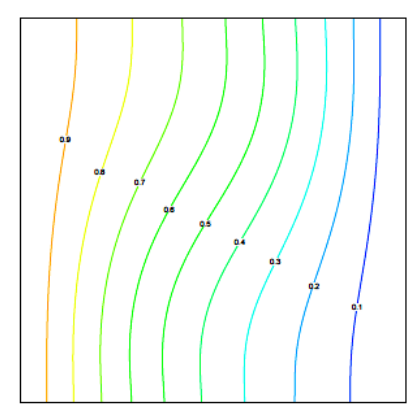

(b)

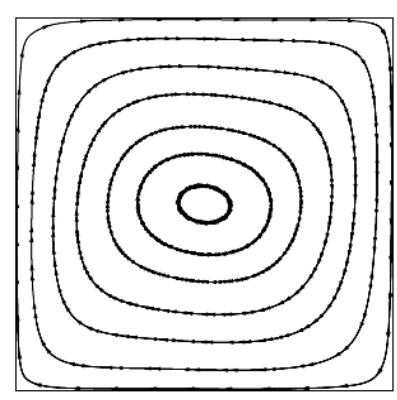

(a) (a) Streamline (b) T contour

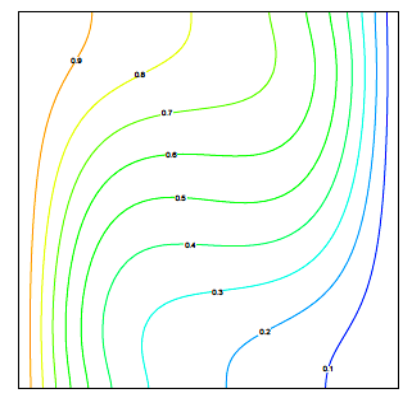

(b)

Fig. 4. $\mathrm{Ra}=10^{4}$ (a) Streamline (b) $\mathrm{T}$ contour

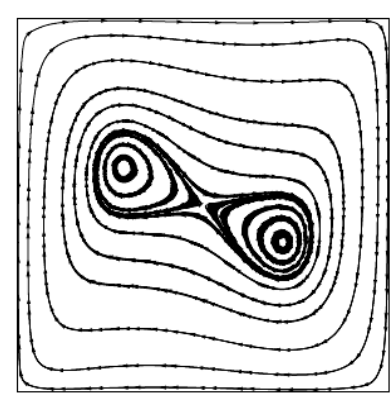

(a)

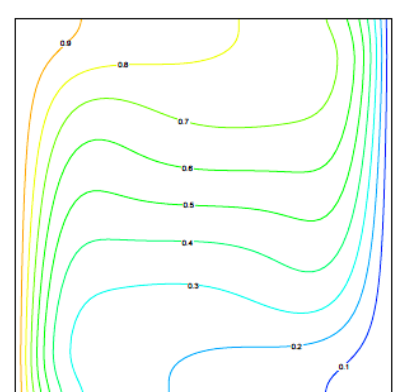

(b)

Fig. 5. $\mathrm{Ra}=10^{5}$ (a) Streamline (b) $\mathrm{T}$ contour 


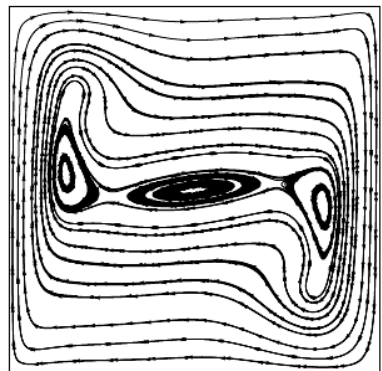

(a)

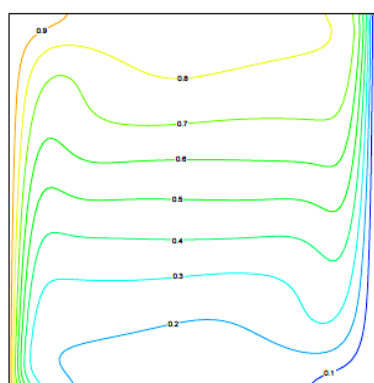

(b)

Fig. 6. $\mathrm{Ra}=10^{6}$ (a) Streamline (b) $\mathrm{T}$ contour

\section{CONCLUSION}

The problem of natural convection of an incompressible, Boussinesq fluid within a rectangular cavity with differentially heated walls (de Vahl Davis [4] problem) was investigated numerically. The computation had been done using complex geometry formulation in non-orthogonal grids. The convergence problem for higher Rayleigh numbers had been experienced. This problem was overcome using small value of pseudo-time step. The results were compared with the benchmark solution of de Vahl Davis [4], Markatos and Perikleous [8] and Hadjisophocleous et al. [7] for $\mathrm{Ra}=10^{3} ; 10^{4} ; 10^{5}, 10^{6}$ and $\mathrm{Pr}=0.71$. Very good agreements were obtained except for the $\mathrm{x}$ and $\mathrm{y}$ location of the maximum $\mathrm{u}$ and $\mathrm{v}$ velocity to the midplane. With increase of $\mathrm{Ra}$, the intensity of convection increased. Small values of the Rayleigh number corresponded to low convective heat transport i.e., the case of pure conduction.

\section{Nomenclature:}

$\begin{array}{ll}\mathrm{Ra} & \text { Rayleigh Number } \\ \mathrm{Pr} & \text { Prandtl Number } \\ N u & \text { Nusselt Number } \\ N u_{\max } & \text { Maximum value of local Nusselt number } \\ & \text { on the boundary at } x=0 \\ N u_{\min } & \text { Minimum value of local Nusselt number } \\ \mathrm{J} & \text { on the boundary at } x=0 \\ u, v & \text { Jacobian } \\ u_{\max } & \text { Dimensionless velocity components in } x \\ & \text { and } y \text { directions } \\ v_{\max } & \text { Maximum horizontal velocity on the } \\ k & \text { vertical mid-plane of the cavity } \\ h & \text { Maximum horizontal velocity on the } \\ \beta & \text { vertical mid-plane of the cavity } \\ \alpha & \text { Thermal conductivity } \\ v & \text { Convective heat transfer coefficient } \\ \eta, \xi & \text { Volumetric expansion coefficients } \\ \text { SIMPLE } & \text { Thermal diffusivity } \\ \text { SIMPLEC } & \text { Kinematic viscosity } \\ \text { QUICK } & \text { Dimensionless curvilinear coordinates } \\ & \text { Semi-Implicit Method for Pressure- } \\ & \text { Linked Equation } \\ & \text { Linked Equation Consistent } \\ & \text { Quadratic Upstream Interpolation for } \\ & \text { Convective Kinematics }\end{array}$

\section{REFERENCES}

[1] S. V. Patankar and D. Spalding, "A Calculation of Time Dependent V Incompressible with Free Surface," International Journal of Heat and Mass Transfer, vol. 15, 1972, pp. 1787-1806.

[2] U. Ghia, K. N. Ghia and C. T. Shin, "High-Re Solutions for Incompressible Flow Using the Navier-Stokes Equations and a Multigrid Method," Journal of Computational Physics, vol. 48, 1982, pp. 387-411.

[3] de Vahl Davis, G., and Jones, I. P., "Natural Convection in a Square Cavity-A Comparison Exercise," International Journal of Numerical Methods in Fluids, Vol. 3, 1983, pp. 227-248.

[4] de Vahl Davis, G., Natural Convection of Air in a Square Cavity: A Benchmark Numerical Solution," International Journal of Numerical Methods in Fluids, Vol. 3, 1983, pp. 249-264.

[5] J. P. Van Doormall and G. D. Raithby, "Enhancements of the Simple Method for Predicting Incompressible Fluid Flows," Numerical Heat Transfer, vol. 7, 1984, pp 147163.

[6] C. R. Maliska and G. D. Raithby, "A Method for Computing Three Dimensional Flows Using Non-Orthogonal Boundary-Fitted Co-Ordinates," International Journal for Numerical Methods in Fluids, vol. 4, 1984, pp. 519-537.

[7] Hadjisophocleous, G. V., Sousa, A. C. M., and Venart, J. E. S., "Prediction of Transient Natural Convection in Enclosures of Arbitrary Geometry using a Non-orthogonal Numerical Model," Numerical Heat Transfer, Vol. 13, 1988, pp 373-392.

[8] Markatos, N. C., and Perikleous, K. A., “ Laminar and Turbulent Natural Convection in an Enclosed Cavity," International Journal of Heat \& Mass Transfer, Vol. 27, No. 5, 1984, pp. 755772.

[9] J. F. Thompson, Z. U. A. Warsi and C. W. Mastin, "Numerical Grid Generation," North Holland,1985.

Author: Ramesh Chandra Mohapatra Reader, Mechanical Department, Department of Mechanical Engineering, Government College of Engineering, Keonjhar, Odisha, India, Phone No. 9438551072

E- mail: rameshmohapatra75@gmail.com 